\title{
Brief Report: Reduction in the Frequency of Needle Recapping by Effective Education: A Need for Conceptual Alteration
}

\author{
W.H. Seto, MD; T.Y. Ching, RN; Y.B. Chu, BSc; F. Fielding, PhD
}

\section{INTRODUCTION}

Education is an important part of the hospital infection control program, and two methods often are recommended. ${ }^{1}$ One is the use of printed materials, and the other is the organization of in-service lectures. Although widely used, there is no documentation of their efficacy in the implementation of infection control policies. We report a study on the conceptual alteration associated with these two educational methods and the relationship between conceptual and behavioral change regarding recapping used needles.

\section{METHODS}

The study was conducted in Queen Mary Hospital, Hong Kong, a large teaching hospital with 1,350 beds and 36 clinical wards. With the introduction of a new sharps box, a policy to discontinue needle recapping was formulated. The policy was first implemented during November 1986 in nine wards randomly selected and divided into three groups (A, $B$ and C) of three wards each. The following wards were selected: one surgical, one gynecological and one medical ward for group A; two surgical wards and the intensive care unit for group $\mathrm{B}$; and two medical and one surgical ward for group $C$.

\section{Phase I: Initial Assessment on Concepts and Practice of Recapping}

All nurses were interviewed personally (Survey 1) before the introduction of the sharps boxes. They

From the Deprtment of Microbiology, University of Hong Kong (Dr. Seto and Mr. Chu), Behavioral Sciences Unit, University of Hong Kong (Dr. Fielding), and the Infection Control Unit, Queen Mary Hospital, Hong Kong (Mr. Ching).

Address reprint requests to Wing Hong Seto, MD, Department of Microbiology, University of Hong Kong, Queen Mary Hospital, New Pathology Building, Hong Kong.

Seto WH, Ching TY, Chu YB, Fielding F. Brief report: reduction in the frequency of needle recapping by effective education: $a$ need for conceptual alteration. Infect Control Hosp Epidemiol. 1990; 11:194-196. were quizzed on their current practice of recapping and on three concepts regarding the correct rationale, method and action for recapping by three respective questions:

1. Do you think that dropping uncapped needles and syringes directly into a sharps box would reduce your risk of contracting bloodborne diseases? Yes/No

2. What do you think is the safest way to dispose of used needles?

a. Needles uncapped into a box, bag, bottle or tin.

b. Needles recapped into a box, bag, bottle or tin.

c. Needles uncapped into a rubbish container.

d. Needles recapped into a rubbish container.

e. Needles uncapped into a formal sharps box. (Correct concept)

f. Needles recapped into a formal sharps box.

3. Should you recap used needles before disposal? Yes/No

\section{Phase II: Introduction of Sharps Boxes and Assessment for Change}

For each of the three groups, different methods were used to introduce the new needle disposal policy. In group A (the control group), the conventional method of communication in Queen Mary Hospital was adopted, i.e., the simple announcement of policy through the charge nurses who were given information on the new policy personally by the infection control nurse (ICN). For group $B$, the passive method group, in addition to the announcement by the charge nurses, four printed posters designed by the University Medical Illustration Unit were posted in each ward beside the injection trolley and in the nurses' duty room. A pamphlet containing the information given to the charge nurses was also distributed to every nurse in the group. In group C, the active method group, posters and pamphlets with a simple announcement were used, but halfhour in-service talks on the information in the pam- 


\begin{tabular}{|c|c|c|c|c|}
\hline \multirow[b]{2}{*}{ Educational Methods $\neq$} & \multicolumn{2}{|c|}{ Conceptual Alterations * } & \multicolumn{2}{|c|}{ Behavioral Alterationt } \\
\hline & $\begin{array}{l}\text { Total Number of } \\
\text { Wrong Concepts } \\
\text { in Survey } 1 \\
\text { (\% of All Concepts) }\end{array}$ & $\begin{array}{c}\% \text { of } \\
\text { Wrong Concepts } \\
\text { Corrected } \\
\text { in Survey } 2 \\
\end{array}$ & $\begin{array}{c}\text { (a) } \\
\% \text { of Nurses } \\
\text { With No } \\
\text { Recapping Reported }\end{array}$ & $\begin{array}{c}\text { (b) } \\
\text { Direct } \\
\text { Needle-Count } \\
\text { Uncapped Total } \\
(\%) \\
\end{array}$ \\
\hline $\begin{array}{l}\text { 1. Group A } \\
\text { Simple announcements } \\
62 \text { nurses } \\
\text { (9) } \neq\end{array}$ & $122_{a}(66)$ & $25_{a}$ & 21 & $\begin{array}{c}39 / 146 \\
(27)\end{array}$ \\
\hline $\begin{array}{l}\text { 2. Group B } \\
\text { Passive method } \\
79 \text { nurses } \\
(23) \neq\end{array}$ & $108_{b}(46)$ & $57 \mathrm{~b}$ & 66 & $\begin{array}{c}86 / 183 \\
(47)\end{array}$ \\
\hline $\begin{array}{l}\text { 3. Group C } \\
\text { Active and passive methods } \\
67 \text { nurses } \\
(11) \ddagger\end{array}$ & $128_{a}(64)$ & $81_{\mathrm{C}}$ & 85 & $\begin{array}{c}94 / 166 \\
(57)\end{array}$ \\
\hline $\begin{array}{l}\text { * Groups with different subscript diffe } \\
\dagger \text { Correlation between (a) and (b) wa } \\
\ddagger \text { Number of nurses with } 3 \text { correct co }\end{array}$ & $\begin{array}{l}\mathrm{p}<.05) \text { by chi-square. } \\
=0.9997, \mathrm{p}<.02) \\
\text { y } 1\end{array}$ & & & \\
\hline
\end{tabular}

phlet also were conducted and attendance was compulsory. This talk was standardized and was given by the infection control officer and the ICN.

Two different methods were used to assess behavior change among the nurses. First, five weeks after the new policy was introduced, a second survey (Survey 2) by personal interview was conducted on the nurses' current practice of needles recapping. The three questions in Survey 1 assessing the nurses' concepts of recapping were also repeated, although in a different order. Second, one day before Survey 2, all sharps boxes used in a 24-hour period were collected unannounced and the number of capped and uncapped needles was counted.

\section{RESULTS}

In the analysis of the data, the 25 nurses who were on leave or who were transferred during Survey 2 and the two nurses who disclaimed recapping in Survey 1 were excluded. The distribution of the remaining 208 nurses in the three study groups is shown in Table 1 . For the three groups, the proportion of nurses with three correct concepts in Survey 1 was comparable $\left(\chi^{2}=5.6, p=.06\right)$, as well as the distribution of nurses by rank $\left(\chi^{2}=6.6, p=.36\right)$. However, the proportion of concepts tested in Survey 1 that was wrong was not comparable $\left(\chi^{2}=21.9, p<\right.$ .001 ), and a significantly smaller proportion (46\%) was found in group B.

The behavioral and conceptual alterations that were noted after the education program are shown in Table 1. No recapping was reported by 122 nurses $(59 \%)$, and the largest percentage $(85 \%)$ occurred in group C, followed by group B (66\%) and group A (21\%). Similarly, for the direct needle-count, $57 \%$ of the needles in group $\mathrm{C}$ were uncapped, followed by $47 \%$ in group B and $27 \%$ in group A. For both measurements, differences between the groups were significant $\left(\chi^{2}=57.3, p<.001\right.$ and $\chi^{2}=29.1, p<.001$ respectively), as well as the correlation between the proportion of nurses with no recapping and the proportion of needles that were uncapped $(r=0.99, p<$ .02 ). This indicates that there is convergent validity in the two methods of measurements. As to wrong concepts in Survey 1 that were corrected, the best result was again in group $C(81 \%)$, followed by group B (57\%) and group A (25\%). The groups differed significantly $(p<.05)$.

When nurses were tabulated according to the number of correct concepts in Survey 2 (Table 2), behavior change was significantly better $(p<.05)$ for those with three correct concepts (93\%) followed by those with two (50\%) and one (10\%). There was, however, no significant difference between nurses with one $(10 \%)$ and no correct concept $(12 \%)$.

There were five reports of needlestick injuries between Survey 1 and Survey 2, but these were too few for comparison between the three groups.

\section{DISCUSSION}

Although education for the discontinuation of needle recapping is widely recommended, ${ }^{2-4}$ there is little documentation of its effectiveness. In fact, several authors have indicated that education may be ineffective in altering the practice. ${ }^{5-7}$ This study, however, shows that recapping can be altered by effective education, but it has to be preceded by conceptual alteration among the subjects. ${ }^{8}$ Both the active and passive methods were significantly better than a simple announcement, but the best 


\begin{tabular}{|c|c|c|}
\hline \multicolumn{3}{|c|}{$\begin{array}{l}\text { Table } 2 \\
\text { Relationship Between Number of Correct } \\
\text { Concepts and Behavioral Change }\end{array}$} \\
\hline $\begin{array}{l}\text { Number of } \\
\text { Correct } \\
\text { Concepts From } \\
\text { Each Nurse in } \\
\text { Survey } 2\end{array}$ & $\begin{array}{c}\text { Number } \\
\text { of } \\
\text { Nurses }\end{array}$ & $\begin{array}{l}\text { Nurses With } \\
\text { No } \\
\text { Recapping } \\
(\%)^{\star}\end{array}$ \\
\hline Three & 112 & $7104_{a}(93)$ \\
\hline Two & 20 & $10_{b}(50)$ \\
\hline One & 50 & $5_{c}(10)$ \\
\hline Zero & 26 & $3_{c}(12)$ \\
\hline \multicolumn{3}{|c|}{$\begin{array}{l}\text { * Groups with different subscript differ significantly }(p<.05) \text { by chi- } \\
\text { square. }\end{array}$} \\
\hline
\end{tabular}

results were noted when the active method was included. Behavior change also was related to the number of correct concepts obtained from each nurse after the education program, except that for those with one and no correct concept, the frequency of recapping was similar. This is probably because for a person to be affected, new concepts must be assimilated and mentally organized into a rational schema ${ }^{9}$ and perhaps this schema is incomplete with just one correct concept. In education, the organization of this schema may be just as important as the alteration of wrong concepts.

It must be conceded in this study that the three groups were not fully comparable. Because of the random selection process, the types of wards were different. Also, group B had a significantly lower percentage of wrong concepts in Survey 1 . However, the best results were still noted in group $\mathrm{C}$ (the active method group) and the relationship between behavior and conceptual change was present in all three groups.

It was not possible in this study to show the relative efficacy of the educational methods in the actual reduction of needlestick injuries because the numbers were too few. Nevertheless, it is reassuring to know that education did have an impact on the recapping practice. Nosocomial infection is associated with incorrect patient care practices ${ }^{10}$ and often these practices must be altered before infection control is possible.

\section{REFERENCES}

1. Hinson PL. Education. In: Soule BM, ed. The APIC Curriculum for Infection Control Practice. Dubuque, Iowa: Kendall/Hunt; 1983.

2. McCormick RD, Maki DG. Epidemiology of needlestick injuries in hospital personnel. Am J Med. 1981;70:928-932.

3. Neuberger JS, Harris J, Kudin WD, Bischone A, Chin TD. Incidence of needlestick injuries in hospital personnel: implications for prevention. Am J Infect Control. 1984;12:171-176.

4. Jackson MM, Dechairo DC, Gardner DF. Perceptions and beliefs of nursing and medical personnel about needle-handling practices and needlestick injuries. Am J Infect Control. 1986;14:1-10.

5. Edmond M, Khakoo R, McTaggart B, Solomon R. Effects of bedside needle disposal units on needle recapping frequency and needlestick injury. Infect Control Hosp Epidemiol. 1988;9:114-116.

6. Krasinski K, LaCouture R, Holzman RS. Effect of changing needle disposal systems on needle puncture injuries. Infect Control. 1987;8:59-62.

7. Riber BS, Landry MN, Gholson GL, Linden LA. Impact of a rigid, puncture resistant container system upon needlestick injuries. Infect Control. 1987;8:63-66.

8. Gagne RM. The Conditions of Learning and Theory of Instruction. 4th ed. New York, NY: CBS College Publishing; 1985.

9. Hamilton DL, Katz LB, Leirer VO. Organization processes in impression formation. In: Hastie R, Ostrom TM, Ebbesen EB, Wyer RS, Hamilton DL, Carlston DE, eds. Person Memory: The Cognitive Basis of Social Perception. Hillsdale, NJ: Erlbaum; 1980:121-153.

10. Haley RW, Garner JS. Infection surveillance and control programs. In: Bennett JV, Brachman PS, eds. Hospital Infections. Boston, Mass: Little, Brown \& Co; 1986:39-50. 